\title{
On Methods of Constructing Integrated Decision-making Model of Investment and Financing in Small and Medium Sized Enterprise
}

\author{
Jiafeng Wan \\ College of Finance and Economics, Jiangxi University of technology, Nanchang, 330098, China
}

Keywords: Small and medium sized enterprises, Integrated decision-making model of investment and financing in small and medium sized enterprises, Industrial structure

\begin{abstract}
Whether in the western developed countries, or in the vast number of developing countries, small and medium enterprises always take a very important position. Especially in China, where there are large quantity of small and medium enterprises, their roles are very significant. The development of small and medium enterprises is conducive to further maintain the vitality of the market economy, to create more employment opportunities and technological innovation, and then to improve the overall economic layout, and promote better development of industrial structure. However, in recent years, the development of small and medium enterprises in China is not optimistic, especially the financial problems are quite prominent, which requires the researches on integrated decision-making model of investment and financing in small and medium sized enterprises in China. This paper analyzes the characteristics and reasons of small and medium enterprises' decision-making of investment and financing, and expounds the main methods of constructing the integrated decision-making model of investment and financing in small and medium sized enterprises, and proposes some suggestions for improving the integrated decision-making model.
\end{abstract}

\section{Introduction}

Integrated decision-making model of investment and financing is main about choosing and deciding the investment and financing plan under the direction of certain goals, mainly for the investment plan of small and medium enterprises, to realize the goal of maximizing the market value of the enterprise. Investment and financing decision-making is the key content that needs to be solved during the pre-project construction, and it is a very important result of the project construction. Projection construction is a very important systematic project, the main characteristics of which is large in scale and complex in structure, requiring large amount of human, financial and material resources, and each investment projects are single and not repeatable. Small and medium-sized enterprises have small scales, insufficient funds and talents, imperfect enterprise management mechanism, and low ability of resisting. Therefore, for small and medium enterprises, the investment decision-making is not simply to choose and judge the project construction scheme, but to create its own sound theoretical framework system, and form a set of standardized decision-making mechanism.

\section{Characteristics and Reasons of Small and Medium Enterprises' Decision-making of Investment and Financing \\ Characteristics of Small and Medium Enterprises' Decision-making of Investment and Financing}

First, small and medium enterprises mainly take the form of internal investment, including the trial-production of new product and the renewal of machinery and equipment. Internal investments in the small and medium sized enterprises in China mainly include the expansion of the current product, the new product development, the transformation and renovation of the equipment, and the human resource investment. Second, foreign investment of small and medium enterprises is mainly direct investment. Some competitive small and medium enterprises can also make a direct foreign investment, which mainly includes the shares, holding and cross industry investment, rather than 
indirect investment like trading stocks or bonds in the securities market. Third, small and medium-sized enterprise investment amount is small. The overall size of small and medium-sized enterprise in China is small, and the gap of the fund is relatively large, so the enterprise is often limited in strength. At the same time, in China' s small and medium enterprises, family enterprises take a large proportion. The talent is very scarce, corporate management mechanism is not sound, corporate reputation and image has not been fully established, and the financial institutions will not invest a large scale of funds to them. So, small and medium enterprise receive limited investment funds. Fourth, the time of investment is short. Once faced with financing difficulties, investment project of small and medium enterprise, rarely for the long-term development, but usually for short-term investment benefits. Over chasing for short-term benefits usually cause the enterprise to ignore the investment for long-term development, so that many of them even do not have a long-term development plan. Fifth, they pay more attention to the market investigation and investment recovery in the investment decision evaluation, but neglect the comprehensive evaluation on the investment and financing projects.

\section{Reasons of Small and Medium Enterprises' Decision-making of Investment and Financing}

First, the shortage of investment greatly limits the investment diversification. The main source of the small and medium-sized enterprise funds are got by the enterprise owner through various channels to get the funds,together with a small portion of the retention fund for profits. In addition to maintaining the normal production and operation, a small portion of the above funds can be used in investment and financing. Small and medium enterprises have narrow ways of financing. External financing is usually dependent on the financial institution's investment or loan. As the enterprises have uneven reputation, it is hard for them to get investment or loan form the financial institutions. In this situation, China' s small and medium enterprises are unlikely to have enough funds for multi-projects. Second, the lack of talented person limits the standardized management of investment and financing project. Since the scale of small and medium-sized enterprises in China is often small, most of which are family enterprises, the lack of investment management knowledge and talents can cause low management ability. Due to their own limited capacity, the investors' decision-making in small and medium enterprises will often be based on their own experience and the popularity of project in the market, which is fateful. In this way, integrated decision-making of investment and financing will be more blind and of risk.

\section{Methods of Constructing Integrated Decision-making Model of Investment and Financing in Small and Medium Sized Enterprise}

\section{Non-discounting Decision-making}

First, payback method. Payback is to make capital budgeting according to how long the net cash flow after tax can recover all the investment, which means to use the time to recover the original investment as the important criterion for investment plan evaluation, also known as payback period method. This method can be used to judge the degree of risk of the project according to the time of the fund use. In terms of fund liquidity, short-term capital flow is often of less risk than the long-term one. In view of this, if the other factors are the same, the shorter recovery period is, the better alternative plan will be. For small and medium enterprises in our country, we can use this method to determine the length of the recovery period and choose a reasonable period of the project, which can effectively control the investment risk caused by the shortage of funds. Second, Average annual rate of return method. This method to make decision on investment mainly based on the high average return rate of investment in the investment plan. Usually, higher annual average return rate means stronger profitability of investment project, and the alternative plan is more desirable. Small and medium enterprises can choose those projects with the average return rate, but must take into account the impact of the recycling period. As the small and medium-sized enterprise' s own ability is limited, it is not allowed to choose the project with high average return rate and long recovery period. Otherwise, bankruptcy may occur before the recovery period for the lack of working capital. 


\section{Discounting Decision-making}

First, net present value method. This method is to make decision by using net present value in the long-term investment decision-making. This method is currently the most widely used. Usually all the future cash flow may be discounted with the cost of project funds. Once the net present value is positive, it will be accepted, or the project will be abandoned. Since this method is popular, it is very suitable for all uniform cash flow, or irregular cash flow, so as to reflect the order cash flow produced in project and the entire life cycle of the income obtained, and then demonstrate the value of money. Those relatively strong projects for a longer period of investment are very applicable for small and medium enterprises. They can effectively help the enterprise to implement long-term effective investment in controllable risk. Naturally, the premise of the method is to have a lot of options with the same investment. Second, profitability index method. This method is to evaluate the profitability of the investment plan based on the discounted monetary value of the future cash flow. This is one of the important methods of decision-making of investment and financing. In this method, the present value of the future cash flow and investment value of the investment projects are compared. The small and medium enterprises can combine this method with the net present value method. Third, internal rate of return method. Internal rate of return mainly refers to the intrinsic rate of return of a project, which is the discount rate of the present value of the cash flow in the present value of the investment. The minimum expected rate of return of small and medium enterprises is now known, mainly put forward by the management layer according to their own reality. If the rate of return contained in a project is greater than the cost of capital, the project may form excessive cash flow after the recovery, which proved that the project is desirable. Because the investors make judgment from their own work experience, so this method can prevent the investors from making blind and subjective judgment.

\section{Suggestions on Improving Integrated Decision-making Model of Integrating Investment and Financing in Small and Medium Sized Enterprise}

\section{To Cultivate The Core Competitiveness of Small and Medium Enterprises on Integrated Decision-making Model of Investment and Financing}

Facing a huge bottleneck, the problem of investment and financing, large number of small and medium enterprises have to make a diversified business investment decisions. At present, China's small and medium enterprise customer groups are relatively small, but their service ability can easily go beyond some of the large and large enterprises. However, the development process from the customer base to the extensive customer group is a qualitative leap for the small and medium-sized enterprise, so the original various business forms and management modes can not meet the requirements of the current market development. Especially for those small and medium-sized enterprises that do not have core competitiveness, this is a very difficult natural barrier to go beyond. Once lacking of core competitiveness, small and medium enterprises will lack of core power for further development. So, for new development, we must focus on integrated decision-making of investment and financing, so as to enhance the core competitiveness and develop strong support force.

\section{To Actively Choose Core Products to Help Small and Medium Enterprises to Form Integrated Decision-making Model of Investment and Financing}

The core products mainly refers to the center products produced after long development, the growth of which will determine the future of the enterprise' s long-term sustainable development. Core products are the shells of core competitiveness, showing the core competitiveness of the enterprise comprehensively. Every small and medium enterprises must have their own core products. Once lacking of appropriate core products, the enterprise may lacking of direction for future development. However profitable the non core products are, they can not replace the important position of the core products. 


\section{To Combine Investment and Financing to Promote integrated Integrated Decision-making of Investment and Financing}

Generally speaking, the investment and financing mainly refers to the behavior of paying the corresponding cash for a project in order to gain more cash in the future. Integrated decision-making of investmen and fiancing mainly refers to paying corresponging cash to get more cash for all the products. Traditional investment and financing is mainly refers to the reasonable and paid mobilization of capital between the supplier and the demander, which is the process of necessary funds circulation and raising for corresponding business. However, the investment based on the subsidary product can also be helpful for funds circulation. Although belonging to investment and financing, but it is not aimed at long-term advantageous development, but for solving the problem of investment and financing in the development of core products, so as to relieve the pressure of decision-making of investment and financing. In this regard, new concept of development may serve as a good example for the development of small and medium enterprises in China, and be of practical significance especially in the current undesirable situation. therefore, the core products and auxiliary products should be coordinated reasonbly in the the investment and financing system of small and medium enterprises, in order to obtain the best results.

\section{To Improve Investment and Financing Guarantee System of Small and Medium Sized Enterprises in China}

A sound and perfect credit guarantee system of small and medium sized enterprises can be an effective method to solve the problem of investment and financing. It can not only enhance the mutual effective cooperation among the credit guarantee agencies, enterprises and financial institutions, but also provide all kinds of loans, in order to make up the shortage of mortgage. In addition, it can effectively reduce the information asymmetry problems existing in enterprises and financial institutions, as well as the risk of investment and financing of banks and other financial institutions to small and medium sized enterprises.

\section{Conclusion}

Generally speaking, small and medium enterprises in China are small size, lacking in capital and talents, imperfect in the enterprise management system. They have low ability to resist risks and difficulties in the external financing. Therefore, it is necessary for us to consider the impact of various factors, make full use of all kinds of methods of investment decision-making, and effectively combine the various problems in production and management, reduce of adverse effects caused by investment risk, and the implement more scientific and effective decision-making of investment and financing, and thus promote better and faster development of small and medium enterprises.

\section{References}

[1] Liu Zhiyuan, Liu Chao. Financial Strategy and Control of Small and Medium Sized Enterprises. Tianjin: People’ s Publishing House, 2003.

[2] Luo Yangdan. Private Financing of Small and Medium Enterprises. Beijing: China Finance Publishing House, 2009.

[3] Luo Haibing. Research on Relationship between Debt Financing and Investment Decision-making of Listed Corporation. Statistics and Decisions, 2011(9).

[4] Xie Mingjia. A study on Relationship between Investment and Financing of Small and Medium Sized Enterprises and Local Investment and Financing. China Business and Trade, 2012(15). 